Statements on funding and competing interests

Funding The author has received honoraria, consulting fees and conference sponsorship from GlaxoSmithKline, Sanofi-Pasteur, Schering-Plough (formerly Organon), Bayer Schering and Wyeth.

Competing interests The author is the Editor-in-Chief of the Journal of Family Planning and Reproductive Health Care.

\section{References}

1 Gladwell M. John Rock's error. The New Yorker, 18 March 2000.

2 Klipping C, Duijkers I, Trummer D, Marr J. Suppression of ovarian activity with a drospirenone-containing oral contraceptive in a 24/4 regimen. Contraception 2008; 78: $16-25$.

3 Milsom I, Korver T. Ovulation incidence with oral contraceptives: a literature review. J Fam Plann Reprod Health Care 2008; 34: 237-246.

4 Edelman A, Gallo MF, Nichols MD, Jensen JT, Schulz KF Grimes DA. Continuous versus cyclic use of combined oral contraceptives for contraception: systematic Cochrane review of randomized controlled trials. Hum Reprod 2006; 21 : 573-578.

5 Archer DF, Jensen JT, Johnson JV, Borisute H, Grubb GS Constantine GD. Evaluation of a continuous regimen of levonorgestrel/ethinyl estradiol: phase 3 study results. Contraception 2006; 74: 439-445.

6 Sulak PJ, Kuehl TJ, Coffee A, Willis S. Prospective analysis of occurrence and management of breakthrough bleeding during an extended oral contraceptive regimen. Am J Obstet Gynecol 2006; 195: 935-941.

7 Coffee AL, Sulak PJ, Kuehl TJ. Long-term assessment of symptomatology and satisfaction of an extended oral contraceptive regimen. Contraception 2007; 75: 444-449.

8 Sulak PJ, Smith V, Coffee A, Witt I, Kuehl AL, Kuehl TJ. Frequency and management of breakthrough bleeding with continuous use of the transvaginal contraceptive ring: a randomized controlled trial. Obstet Gynecol 2008; 112: 563-571.

9 Electronic Medicines Compendium. NuvaRing: Summary of Product Characteristics. 23 January 2009. http://emc. medicines.org.uk/document. aspx?documentld=21419 [Accessed 18 February 2009].

10 Glasier AF, Smith KB, van der Spuy ZM, Ho PC, Cheng L, Dada $\mathrm{K}$, et al. Amenorrhea associated with contraception - an international study on acceptability. Contraception 2003; 67: $1-8$.

11 Weisberg E. Judaism and women's health. J Fam Plann Reprod Health Care 2009; 35: 53-55.

\title{
FICTION BOOK REVIEWS
}

The Memory Keeper's Daughter. Kim Edwards. London, UK: Penguin Books, 2007. ISBN-13: 978-0-14103-014-2. Price: £7.99. Pages: 416 (paperback)

On a snowy winter's night back in the early 1960s in a provincial American town a doctor rushes his wife to his surgery to give birth, assisted by his devoted nurse. The couple are not aware that she is carrying twins and the doctor uses sedation for the delivery of the second twin. $\mathrm{He}$ is shocked to discover that the baby has Down's syndrome - a condition that affected his own sister with devastating consequences. A few hours later, an irrevocable - and to our Noughties eyes, a terrible - decision is taken which has profound and far-reaching effects, both on the main characters of the book as well as on those who appear tangentially throughout.

Without consulting his wife, he arranges for the baby to be taken by the nurse to a residential home but tells his wife that the baby has died.

The book spans the 25 years from 1964 to 1989 and the history of the doctor, his wife and progeny and the nurse who was present at the birth. The attitudes of the times are well presented and the psychological backgrounds are very credible.

Despite the horror of the original decision, it must have been one that was in truth taken many, many times. What makes this narrative unusual is that it has a redemptive element that, sadly, probably happens rarely in 'real' life. But it is not a 'happy ending' book, rather one that presents options

I found this a beautifully written story with believable, if not always loveable, characters whose motivations and actions are understandable.
The narrative is told simply and well and has an almost televisual quality in its detail.

The book is not about medicine per se, but it would be of interest to doctors, nurses and all those who work in reproductive health. It is an easy, if not comfortable, read.

Reviewed by Judy Bud, Dip Psych

Transpersonal Psychotherapist, London, UK

Touching Distance. Rebecca Abrams. London, UK: Macmillan, 2008. ISBN-13: 978-0-23001555-5. Price: £12.99. Pages: 310 pages (hardback)

This historical novel is set in the 'granite city' of Aberdeen in the last decade of the 18th century during the Age of Enlightenment.

The book is based on fact and tells the story of Dr Alec Gordon, newly appointed physician in the Aberdeen Dispensary. This prestigious appointment has been quickly gained as Dr Gordon has recently returned from training at one of the great European medical schools. Although benefiting from the latest medical thinking and new ideas, we find Dr Gordon struggling desperately in the darkness of ignorance to fight an epidemic that suddenly strikes and kills newly delivered mothers across the region.

The author has clearly researched the content of the book to an exceptionally high standard. Having done so, she does not hesitate to write about the full range of symptoms of this "mysterious" disease in realistic detail in its progression to the point of death. This is not a book for the squeamish. Various treatments are tried by the good doctor, all of which are accurate representations of medical ideas in use at the time in the British Isles and in parts of Europe. The failure of these treatments within the limitations of the late 18 th century make the doctor more and more desperate as he sets off at all hours of the day and night to attend patients, often in the poorest of districts.

The society of North East Scotland across the classes is as carefully researched as is the medical history. A whole range of life is presented from housing to clothes to food and even dialect. Just beneath the surface of the desperate struggle Dr Gordon is experiencing are professional politics, jealousies and the deep suspicion felt by some about accepting new medical concepts that could fit in as well in the 21 st century as in the 18 th century.

As failure sets in, so does panic, and we see Dr Gordon trying to sustain public and personal confidence in his abilities and the medical profession as a whole. Not content with this overwhelming situation, Alec Gordon has to deal with an unhappy home life as his wife struggles with her own mental illness. Despite all this, there are some welcome moments of light and relief in a background of passion.

Touching Distance is dark and fascinating and works at many levels as a novel. It is a story of courage and tenacity and a whole new way of medical thinking. The sheer determination of our medical fathers and scientists against all the odds during an epidemic is extraordinary and moving. The author, Rebecca Abrams, gives the people of the time real life in the pages of this book.

\section{Reviewed by Lesley Smith}

Medical Historian and Curator, Tutbury Castle, Staffordshire, $U K$

We hope that journal readers enjoyed reading The Memory Keeper's Daughter, and also discovering whether their opinion of the book matched that of our guest reviewer. In the July 2009 issue, the fiction book under scrutiny will be Tell It To The Bees by Fiona Shaw (304 pages, Tindal Street Press, 2009 , ISBN13: 978-0-95564-766-6, to be published on 21 May 2009 priced at £9.99).

We want to remind journal readers that if they would like to offer to review an appropriate fiction title of their own choosing then they should contact the Journal Editorial Office by e-mail (journal@fsrh.org) in the first instance with details of their nominated title.

\section{Visit the Faculty Website at www.fsrh.org}

